\title{
Optimization of emission reducing energy retrofits in Finnish apartment buildings
}

\author{
Janne Hirvonen ${ }^{1, *}$, Juha Jokisalo ${ }^{1}$, Juhani Heljo ${ }^{2}$ and Risto Kosonen ${ }^{1}$ \\ ${ }^{1}$ Aalto University, Department of Mechanical Engineering, PO Box 14400, 00076 Aalto, Finland \\ ${ }^{2}$ Tampere University of Technoloy, Department of Civil Engineering, PO Box 527, 33101, Tampere, Finland
}

\begin{abstract}
This study examined the cost-optimality of energy renovation on Finnish apartment buildings of different ages, built according to different energy performance requirements. Multi-objective optimization was utilized to minimize both $\mathrm{CO}_{2}$ emissions and life cycle cost (LCC). IDA-ICE simulations were performed to obtain the hourly heating demand of the buildings. Four building age classes and three heating systems (district heating, exhaust air heat pump and ground-source heat pump) were separately optimized. With district heating, it was possible to reduce emissions by $11 \%$, while also reducing LCC. With heat pumps cost-savings could be achieved while reducing emissions by over $49 \%$. With maximal (not costeffective) investments, emissions could be reduced by more than $70 \%$ in all examined cases. In all cases, the cheapest solutions included solar electricity and sewage heat recovery. In old buildings, window upgrades and additional roof insulation were cost-effective. In new buildings, demand-based ventilation was included in all optimal solutions.
\end{abstract}

\section{Introduction}

The EU has plans to reduce greenhouse gas emissions by $40 \%$ relative to 1990 levels by the year 2030 [1] and by $80 \%$ by the year 2050 [2]. A major part of emissions and energy consumption happens in buildings [3]. This is why the Energy Performance of Buildings Directive (EPBD) [3] declares that all new buildings should be nearly zero energy buildings by the end of the year 2020 . However, most of the building stock consists of old, low performance buildings. Thus, energy renovations must be performed on the old buildings, to bring their emissions closer to the current standards.

Apartment buildings and single family houses make up most of the building stock in Finland and require special focus. This study examines the costoptimality of energy renovation on apartment buildings of different ages, built according to different energy performance requirements. Multi-objective optimization to minimize both $\mathrm{CO} 2$ emissions and life cycle cost is utilized.

\section{Methods}

This study is based on dynamic simulation of building energy performance. IDA-ICE software was used for hourly simulation of the building envelope, while MATLAB was used for pre- and post-processing and for calculating the performance of heating systems. Optimization was performed using the genetic algorithm NSGA-II. The calculations were based on the climate of
Southern Finland, using the Finnish test reference year (TRY2012) [4].

Four different age classes of apartment buildings (AB) were modelled and optimized separately to find the retrofit potential for the whole apartment building stock. The age classes were chosen according to changes in the Finnish building regulations [5]. Their properties are shown in Table 1. The amount of apartment buildings constructed in different years in Finland is shown in Figure 1. The older apartment building type (AB1) represented the buildings that were built before any building energy regulations, prior to the year 1976. The second building class (AB2) represents the largest group of buildings, built between 1976 and 2002, according to the building code of the time. Both these types have high space heating consumption because ventilation heating is covered by the space heating system and because there is no ventilation heat recovery. Buildings from 2003-2009 (AB3) adhere to stricter energy performance standards and the newest buildings built after 2010 (AB4) are even more energy efficient. Both are equipped with ventilation heat recovery (HR) and good thermal insulation, which is why most of their heating demand is caused by domestic hot water use.

Three different heating systems were used in the buildings:

(1) District heating only (DH)

(2) Ground-source heat pump with electric backup heating (GSHP)

(3) Exhaust air heat pump with district heating backup (EAHP).

\footnotetext{
* Corresponding author: janne.p.hirvonen $@$,aalto.fi
} 
Table 1. Properties of the four reference buildings and HVAC

\begin{tabular}{|c|c|c|c|c|}
\hline Type name & AB1 & AB2 & AB3 & AB4 \\
\hline Construction years & -1975 & $1976-2002$ & $2003-2009$ & $2010-2020$ \\
\hline \multicolumn{5}{|l|}{$\begin{array}{l}\text { U-values of envelope } \\
\left(\mathrm{W} / \mathrm{m}^{2} \mathrm{~K}\right)\end{array}$} \\
\hline External wall & 0.81 & 0.34 & 0.25 & 0.17 \\
\hline Floor & 0.47 & 0.38 & 0.27 & 0.16 \\
\hline Roof & 0.47 & 0.26 & 0.17 & 0.09 \\
\hline Doors & 2.2 & 1.4 & 1.4 & 1 \\
\hline Windows & 1.7 & 1.7 & 1.4 & 1 \\
\hline $\begin{array}{l}\text { Glazing properties } \\
\text { Total solar heat } \\
\text { transmittance }(\mathrm{g})\end{array}$ & 0.71 & 0.71 & 0.6 & 0.5 \\
\hline Direct solar transmittance (ST) & 0.64 & 0.64 & 0.54 & 0.45 \\
\hline \multicolumn{5}{|l|}{ Air tightness } \\
\hline $\mathrm{n}_{50},(1 / \mathrm{h})$ & 3.2 & 1.0 & 0.9 & 0.7 \\
\hline $\mathrm{q}_{50} \mathrm{~m}^{3} /\left(\mathrm{h} \mathrm{m}^{2}\right)$ & 9.7 & 2.6 & 2.0 & 1.5 \\
\hline $\begin{array}{l}\text { Ventilation } \\
\text { Type }\end{array}$ & Mech exh & Mech exh & Mech sup-exh & Mech sup-exh \\
\hline Heat recovery efficiency & 0 & 0 & 0.60 & 0.65 \\
\hline Air exchange rate $(1 / \mathrm{h})$ & 0.5 & 0.5 & 0.5 & 0.5 \\
\hline $\operatorname{SFP}\left(\mathrm{kW} / \mathrm{m}^{3} / \mathrm{s}\right)$ & 1.5 & 1.5 & 2.5 & 2 \\
\hline Supply air temperature $\left({ }^{\circ} \mathrm{C}\right)$ & Ambient & Ambient & 18 & 18 \\
\hline $\begin{array}{l}\text { Water radiator design } \\
\text { temperatures }\left({ }^{\circ} \mathrm{C}\right) \\
\text { Heat distribution } \\
\text { efficiency }\end{array}$ & $70 / 40$ & $70 / 40$ & $70 / 40$ & $45 / 35$ \\
\hline Room air temperature setpoint $\left({ }^{\circ} \mathrm{C}\right)$ & 22 & 22 & 21.5 & 21 \\
\hline Heated net floor area $\left(\mathrm{m}^{2}\right)$ & 4050 & 2638 & 1585 & 1585 \\
\hline Envelope area $\left(\mathrm{m}^{2}\right)$ & 3540 & 2659 & 1871 & 1871 \\
\hline Window area $\left(\mathrm{m}^{2}\right)$ & 464 & 170 & 156 & 156 \\
\hline Total air volume $\left(\mathrm{m}^{3}\right)$ & 10653 & 6906 & 4120 & 4120 \\
\hline
\end{tabular}




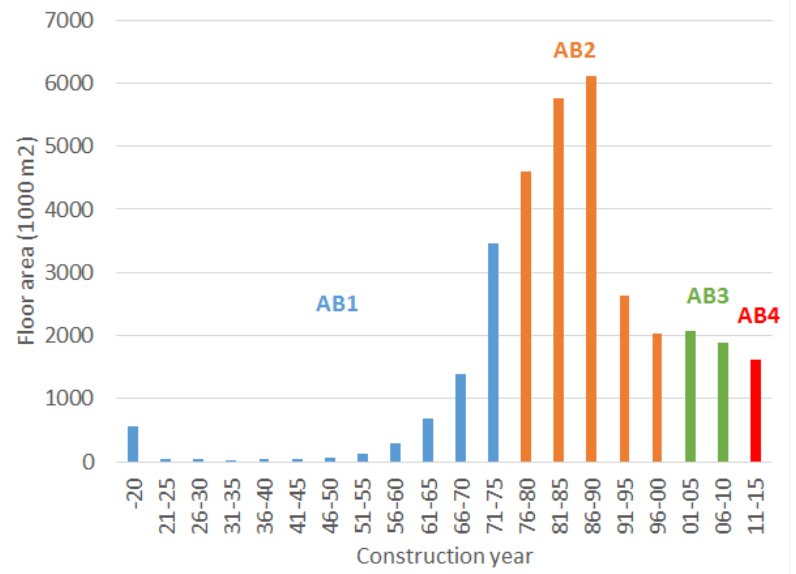

Fig. 1. Floor areas of existing Finnish apartment buildings. Periods of different building codes (AB1-AB4) are identified by different colors.

The efficiency of ventilation heat recovery in the new buildings $\mathrm{AB} 3$ and $\mathrm{AB} 4$ was 60 and $65 \%$, respectively. In the older buildings $\mathrm{AB} 1$ and $\mathrm{AB} 2$, which did not have ventilation HR by default, a newly added HR system had an efficiency of $72 \%$. Heat recovery of sewage was assumed to have constant efficiency of $30 \%$ when only heat exchangers were used (passive HR), but this was increased to $70 \%$ if heat pumps were also utilized (active HR).

Emissions of district heating were assumed to be constant at $176 \mathrm{~kg}-\mathrm{CO} 2 / \mathrm{MWh}$ [6]. Emissions of electricity generation were assumed to vary monthly, so that the minimum average emissions were in July at 81 $\mathrm{kg}-\mathrm{CO}_{2} / \mathrm{MWh}$ and the maximum emissions in February at $174 \mathrm{~kg}-\mathrm{CO}_{2} / \mathrm{MWh}$. A low emission factor in the summer months reduces the benefit of solar energy, because there is significant seasonal variation of solar generation in high latitudes and most of the annual solar energy in Finland is generated during the summer months while almost no solar energy is available in winter.

Optimization of each heating system and building age class was performed separately. The renovation measures used as optimization variables were increased thermal insulation of walls, roof and doors, thermally improved windows, use of sewage heat recovery with an without heat pump (passive/active), utilization of ventilation heat recovery and demand-based ventilation (lower air flow for empty apartments) as well as the installation of solar thermal and solar electric systems. For the heat pump cases, the capacity of the heat pumps was also varied.

\subsection{Economic assumptions}

The building and energy system simulation was performed for a single year, but the life cycle cost (LCC) was determined over a period of 25 years. LCC included system maintenance, renewal and energy import costs. Discounting was done by using a real interest rate of $3 \%$ and energy price escalation rate of $2 \%$.
The cost of district heating was varied seasonally, so that the minimum price in summer was $33.4 € / \mathrm{MWh}$ and the maximum price in winter was $60.5 € / \mathrm{MWh}$.

The price of electricity was composed of three parts: the hourly Nord Pool spot price and the constant distribution cost and electricity tax. When purchasing electricity from the grid, the total value of all three factors was used as the price, but when exporting excess electricity back to the grid, only the spot price was used. The electricity price was varied hourly according to the Nord Pool spot prices. The average hourly spot price for electricity was $39.4 \pm 10.2 € / \mathrm{MWh}$. The distribution cost and electricity tax were fixed at 36.1 and $27.9 € / \mathrm{MWh}$. In total, the import price of electricity was $103 € / \mathrm{MWh}$. Since the TRY2012 weather profile did not match any specific year, a synthetic spot price profile was utilized. The profile was generated from the spot price profiles from years 2010-2017 [7] by adjusting the starting days so that each profile started on the same weekday. Then the average price for each hour was used as the final price profile. The average hourly spot price was $39.4 \pm$ 10.2 €/MWh. The distribution cost and electricity tax were fixed at 36.1 and $27.9 € / \mathrm{MWh}$.

\section{Results}

Figure 2 shows the heating demand in the reference buildings before any renovation measures have been applied. In $\mathrm{AB} 1$ and $\mathrm{AB} 2$ space heating dominated the energy demand, because of poor thermal insulation levels and because heating of fresh air was also covered by the space heating system. AB3 and AB4 included separate ventilation heating as well as a heat recovery system, which reduced the total heating demand.

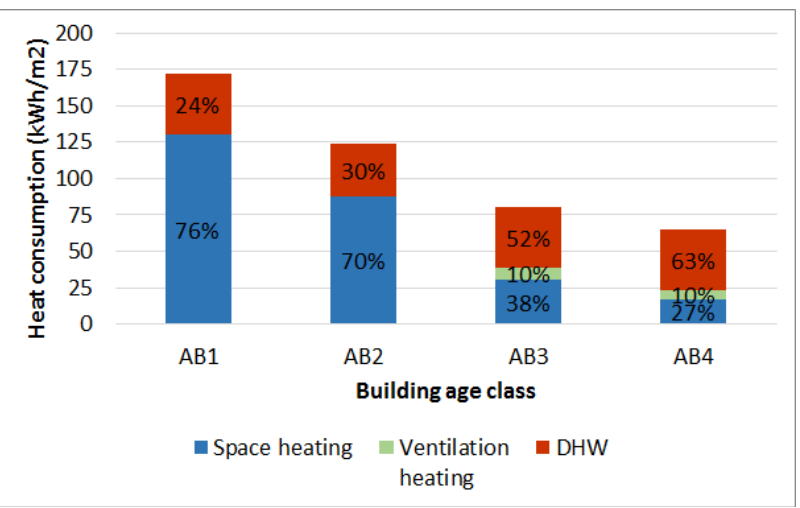

Fig. 2. Heat consumption of space heating, ventilation and domestic hot water in the four reference buildings.

Multi-objective optimization of the energy renovations revealed dozens of Pareto optimal solutions for each building type and heating system. Table 2 highlights four such solutions for each of the heating systems associated with the oldest building type AB1. The solutions were chosen according to their life cycle cost, to get a range of solutions from different investment levels. Solution $a$ is the maximum cost solution which provides the greatest emission reductions, $b$ is an average cost solution, $c$ is has the same LCC as the reference case and $d$ is the least cost solution. 
Table 2. Details of several optimal solutions for AB1. a) Lowest emission solution, b) Average cost solution, c) Cost-neutral solution, d) Least cost solution, Ref) Reference case

\begin{tabular}{|c|c|c|c|c|c|c|c|c|c|c|c|c|c|c|}
\hline \multirow[b]{2}{*}{$\begin{array}{l}\text { Solution } \\
\text { type }\end{array}$} & \multirow{2}{*}{$\begin{array}{c}\mathrm{kg}-\mathrm{CO}_{2} / \\
\left.\mathrm{m}^{2} / \mathrm{a}\right) \\
\\
\text { Emissions }\end{array}$} & \multirow{2}{*}{$\begin{array}{l}(\%) \\
\text { Relative } \\
\text { reduction }\end{array}$} & \multirow{2}{*}{$\begin{array}{c}€ / \mathrm{m}^{2} / \\
25 \mathrm{a}) \\
\\
\mathrm{LCC} \\
\end{array}$} & \multirow{2}{*}{$\begin{array}{c}\left(€ / \mathrm{m}^{2}\right) \\
\text { Investment } \\
\text { cost } \\
\end{array}$} & \multirow[b]{2}{*}{ Walls } & \multicolumn{3}{|c|}{ U-values $\left(\mathrm{W} / \mathrm{m}^{2} \mathrm{~K}\right)$} & \multirow{2}{*}{$\begin{array}{l}\left(\mathrm{m}^{2}\right) \\
\mathrm{ST} \\
\end{array}$} & \multirow{2}{*}{$\begin{array}{c}\left(\mathrm{kW}_{\mathrm{p}}\right) \\
\mathrm{PV}\end{array}$} & \multirow{2}{*}{$\begin{array}{c}\left(\mathrm{kW}_{\mathrm{th}}\right) \\
\mathrm{HP}\end{array}$} & \multirow[b]{2}{*}{ Ventilation } & \multirow[b]{2}{*}{ Radiators } & \multirow[b]{2}{*}{$\begin{array}{c}\text { Sewage } \\
\text { HR }\end{array}$} \\
\hline & & & & & & Roof & Doors & Windows & & & & & & \\
\hline \multicolumn{15}{|c|}{ Apartment building (AB1) with district heating $(\mathrm{DH})$} \\
\hline $\mathrm{a}$ & 9.5 & 72 & 559 & 498 & 0.1 & 0.06 & 1 & 0.6 & 125 & 25 & 0 & $\mathrm{HR}+\mathrm{DBV}$ & $70 / 40$ & Active HR \\
\hline $\mathrm{b}$ & 16.0 & 54 & 459 & 339 & 0.36 & 0.08 & 2.2 & 0.8 & 55 & 30 & 0 & $\mathrm{HR}+\mathrm{DBV}$ & $70 / 40$ & Passive HR \\
\hline $\mathrm{c}$ & 24.7 & 28 & 400 & 156 & 0.81 & 0.08 & 2.2 & 0.7 & 55 & 30 & 0 & No HR & $70 / 40$ & Active HR \\
\hline $\mathrm{d}$ & 28.6 & 17 & 382 & 122 & 0.81 & 0.1 & 2.2 & 0.8 & 5 & 35 & 0 & No HR & $70 / 40$ & Passive HR \\
\hline Ref & 34.4 & - & 400 & 70 & 0.81 & 0.47 & 2.2 & 1.7 & 0 & 0 & 0 & No HR & $70 / 40$ & No HR \\
\hline \multicolumn{15}{|c|}{ Apartment building (AB1) with a ground-source heat pump (GSHP) and electric backup heating } \\
\hline $\mathrm{a}$ & 4.9 & 86 & 561 & 545 & 0.1 & 0.06 & 0.7 & 0.6 & 145 & 20 & 115 & $\mathrm{HR}+\mathrm{DBV}$ & $45 / 35$ & Passive HR \\
\hline $\mathrm{b}$ & 5.5 & 84 & 478 & 443 & 0.23 & 0.1 & 0.7 & 0.8 & 0 & 35 & 115 & $\mathrm{HR}+\mathrm{DBV}$ & $45 / 35$ & Passive HR \\
\hline $\mathrm{c}$ & 7.0 & 80 & 397 & 296 & 0.36 & 0.08 & 0.7 & 0.7 & 60 & 35 & 110 & No HR & $45 / 35$ & Active HR \\
\hline $\mathrm{d}$ & 9.6 & 72 & 316 & 155 & 0.81 & 0.13 & 2.2 & 0.8 & 0 & 30 & 135 & No HR & $70 / 40$ & Passive HR \\
\hline \multicolumn{15}{|c|}{ Apartment building (AB1) with an exhaust air heat pump (EAHP) and district heating backup } \\
\hline $\mathrm{a}$ & 8.8 & 75 & 504 & 399 & 0.1 & 0.06 & 0.7 & 0.6 & 90 & 30 & 39 & No HR & $45 / 35$ & Active HR \\
\hline $\mathrm{b}$ & 9.3 & 73 & 451 & 338 & 0.13 & 0.06 & 0.7 & 0.6 & 75 & 30 & 39 & No HR & $70 / 40$ & Active HR \\
\hline $\mathrm{c}$ & 10.9 & 68 & 401 & 265 & 0.23 & 0.1 & 1 & 0.8 & 0 & 40 & 35 & No HR & $70 / 40$ & Active HR \\
\hline $\mathrm{d}$ & 17.7 & 49 & 355 & 143 & 0.81 & 0.19 & 2.2 & 0.8 & 0 & 35 & 35 & No HR & $70 / 40$ & Active HR \\
\hline
\end{tabular}

\footnotetext{
*orresponding author: janne.p.hirvonen@aalto.fi
} 


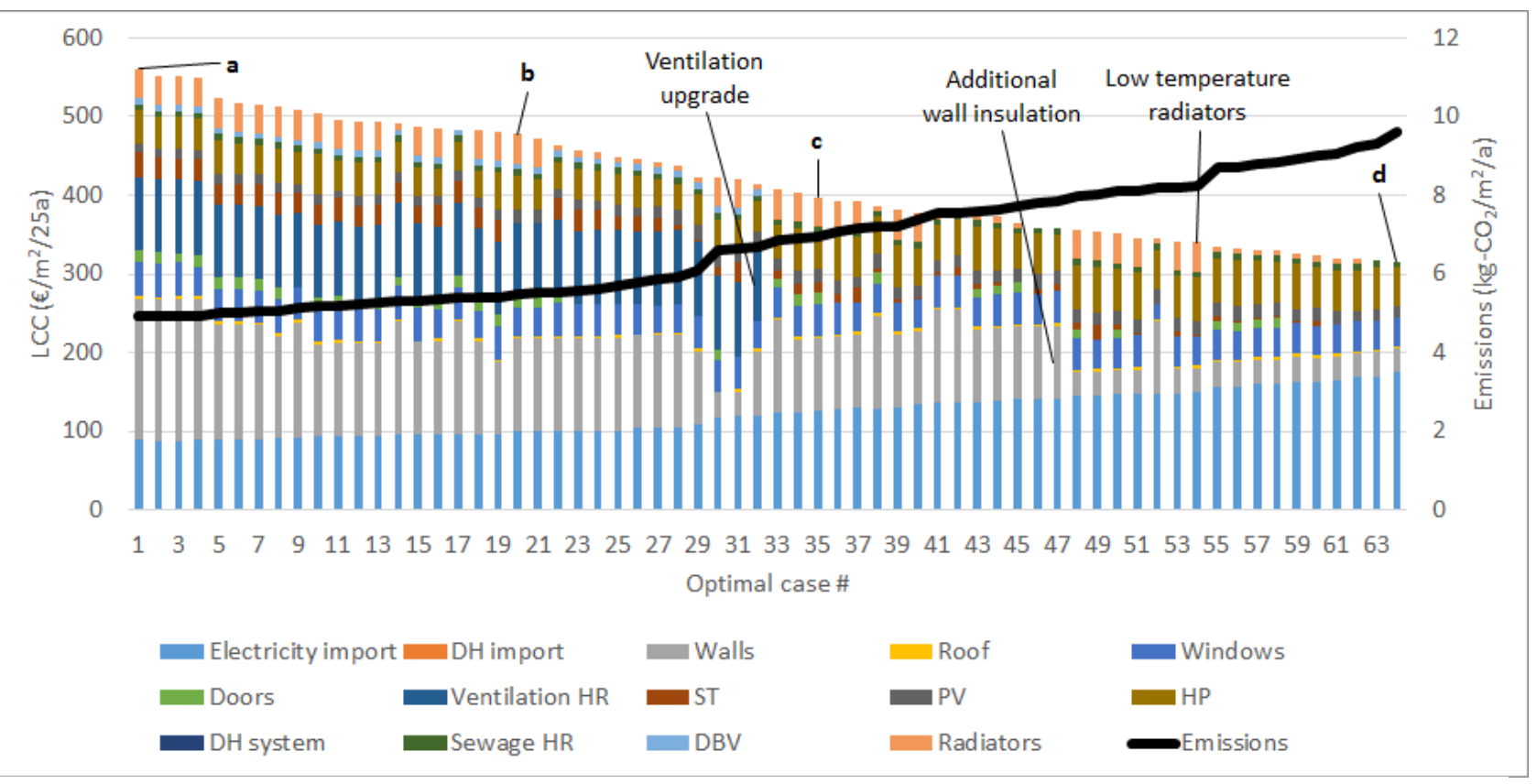

Fig. 3. The annual emissions and life cycle cost distribution in the optimal solutions of the case AB1 with GSHP.

The results show that significant reductions in emissions can be made even without increasing the life cycle cost. The least-cost solution in $\mathrm{AB} 1 \mathrm{DH}$ case reduced emissions by $17 \%$ and had a lower LCC than the reference case without any renovation. This could be improved to $28 \%$ reduction by increasing investments to cost neutral levels. However, to reduce emissions by more than 50\% required an uneconomical amount of additional investments. Upgrading the old building to have mechanical supply-exhaust ventilation with heat recovery and adding more thermal insulation to the walls had significant emission reducing effects, but from a purely monetary point of view they were not feasible. Installation of solar electricity and improved windows and adding more insulation to the roof, however, was economical to do. Heat recovery from sewage was also included in every renovation configuration.

Heat pump solutions turned out to be very costeffective means of emissions reductions. The exhaust air heat pump provided emissions reductions in the range of 49 to $75 \%$. With a ground-source heat pump, even the least-cost solution reduced emissions by $72 \%$. This was due to the low emissions of electricity generation in the Finnish grid compared to district heat generation. The electricity mix includes significant amounts of emission free nuclear and hydro power as well as some wind power, while district heating is mostly based on combustion. Figure 3 shows the cost distribution in the optimal solutions for the AB1 GSHP case. On the high emission side of the figure, the greatest cost components are heat pump installation and purchased electricity. As more measures are used to reduce emissions, the cost of the heat pump and its operation go down. Other large investments are the additional thermal insulation of external walls and the installation of mechanical ventilation with heat recovery. The wall insulation was found cost-effective only in the
Solar thermal collectors were useful with all heating types, but not at all investment levels. Solar electric panels on the other hand had a higher priority in the investment order and were included in every optimal configuration.

Figure 4 provides an overview of the optimal renovations, by showing the LCC and emissions of every Pareto optimal configuration for all buildings and heating systems. It also highlights the position of the chosen solutions from Table 2 on the Pareto front. LCC and emissions of the reference cases are marked with diamond shapes. All building types could be improved cost-effectively and heat pumps proved to be the most efficient solution. The starting efficiency levels of AB3 and $\mathrm{AB} 4$ were already so high that in the heat pump scenarios, most investments had almost no effect on the emissions. A wide range of solutions with different cost were available for the district heated cases of all buildings.

In the district heating cases, cost-effective retrofits, which did not increase LCC, produced emission reductions of $9.7,9.2,7.7$ and $6.8 \mathrm{~kg} / \mathrm{m}^{2} / \mathrm{a}$ for the buildings $\mathrm{AB} 1, \mathrm{AB} 2, \mathrm{AB} 3$ and $\mathrm{AB} 4$, respectively. With the exhaust air heat pump the reductions were 23.5 and $15.0 \mathrm{~kg} / \mathrm{m}^{2} / \mathrm{a}$ for buildings $\mathrm{AB} 1$ and $\mathrm{AB} 2$. Using a ground-source heat pump the cost-effective reductions were the highest, $27.4,20.7,13.2$ and $11.1 \mathrm{~kg} / \mathrm{m}^{2} / \mathrm{a}$ for $\mathrm{AB} 1, \mathrm{AB} 2, \mathrm{AB} 3$ and $\mathrm{AB} 4$, respectively.

\section{Discussion}

The greatest emission reductions were gained by changing the heating system from district heating to heat pumps. This is because of both the lower effective cost and the lower emission factor of electricity compared to district heating. The caveat is the assumption of the average electricity generation mix staying the same in the long term. The results hold for the single building

* Corresponding author: janne.p.hirvonen@aalto.fi 


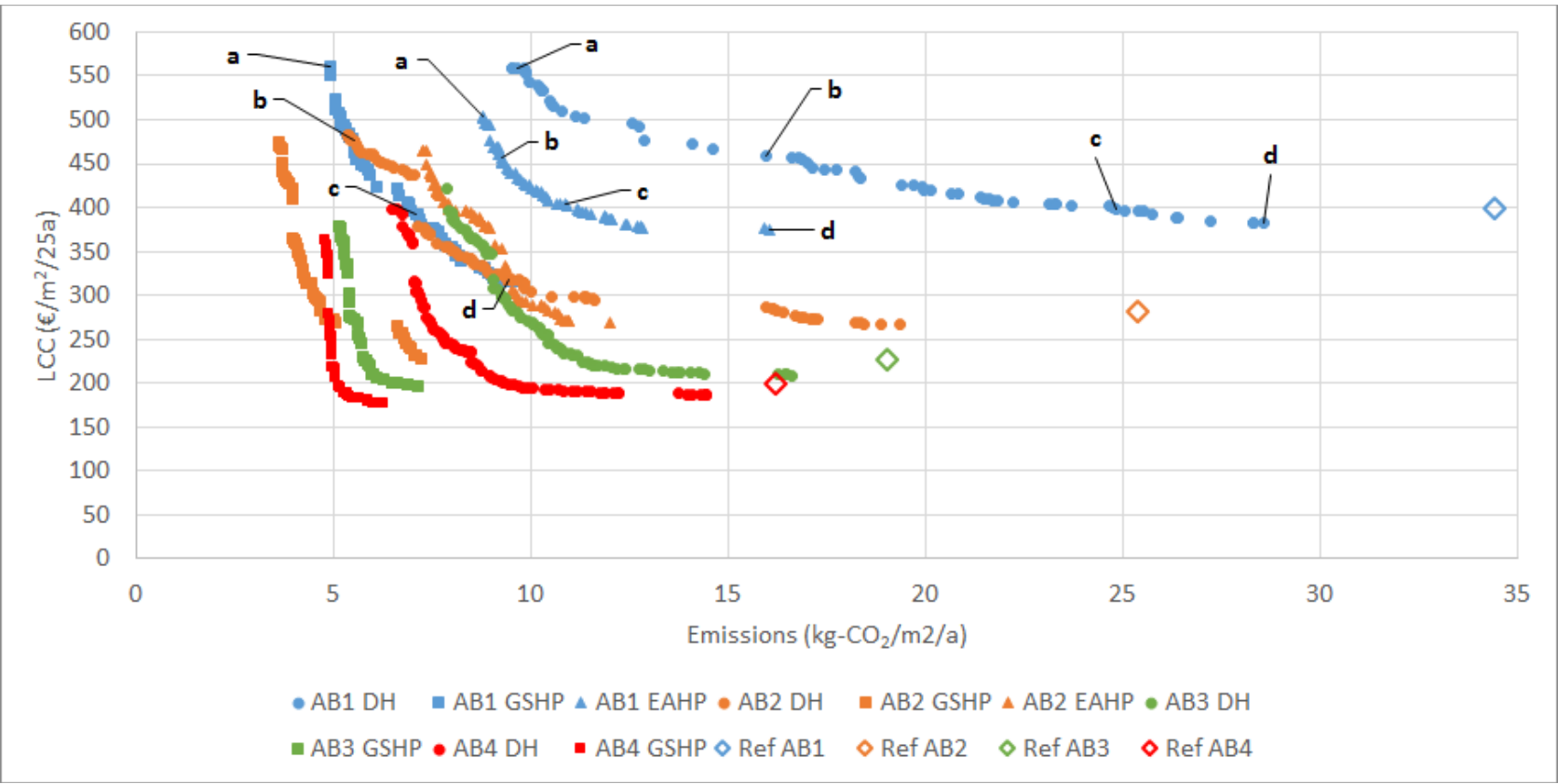

Fig. 4. The annual emissions and life cycle cost for the optimally renovated cases of all buildings and systems. Reference cases are presented as diamond shapes.

case, but if a large amount of consumers would switch to electric heating, this would have an effect on the peak electricity usage and thus on the marginal emissions, as more use of high emission peak power plants would be needed. This would also affect the price of electricity. For low emissions through electrified heating to succeed, more low emission energy sources are needed, which in Finland means mostly wind and nuclear power.

The initial investment needed for significant emission reduction was between 120 and $550 € / \mathrm{m}^{2}$. Most of the old buildings that have the greatest potential for energy retrofits are also require renovations to their water pipes, which have an average investment cost of $600 € / \mathrm{m}^{2}$ [8]. Clearly even larger investments are routinely being made to these old buildings. Some of the energy renovation costs could be absorbed by mandatory renovations of other building components. For example, the retrofit of the ventilation system could be performed alongside the pipe renovation. A tax neutral support scheme, similar to one successfully utilized in Estonia [9], could also be used to encourage energy retrofits in old apartment buildings.

\section{Conclusions}

Cost-effective emission reductions can be done in Finnish apartment buildings. Reductions as high as $80 \%$ are possible, which helps to achieve the European Union's targets of emission reductions for the year 2050.

\section{References}

[1] European Commission, "2030 climate \& energy framework", (2018). [Online]. Available:

https://ec.europa.eu/clima/policies/strategies/2030_en.
[2] European Commission, "2050 low-carbon economy", (2018). [Online]. Available:

https://ec.europa.eu/clima/policies/strategies/2050_en.

[3] The European Parliament and the Council of the European Union, "DIRECTIVE 2010/31/EU of the European Parliament and of the Council of 19 May 2010 on the energy performance of buildings" (2010).

[4] T. Kalamees, K. Jylhä, H. Tietäväinen, J. Jokisalo, S. Ilomets, R. Hyvönen and S. Saku, Energ. Buildings, 47, 53-60 (2012).

[5] Ministry of the Environment, "Directive on building energy certificates, Attachment 1 [In Finnish]," (2017) [Online]. Available:

https://www.finlex.fi/data/sdliite/liite/6822.pdf.

[6] Motiva, "CO2 emissions factors for district heating," (2017). [Online]. Available:

https://www.motiva.fi/ratkaisut/energiankaytto_suomess a/co2-

laskentaohje_energiankulutuksen_hiilidioksidipaastojen_ laskentaan/co2-paastokertoimet.

[7] Nord Pool, "Historical market data, hourly electricity prices," (2018). [Online]. Available:

https://www.nordpoolgroup.com/historical-market-data/.

[8] Taloustaito, "Prices of pipe renovations" (2017).

[Online]. Available:

https://www.taloustaito.fi/koti/suunnitteillaputkiremontti--nousevatko-hinnat/

[9] K. Kuusk and T. Kalamees, Energy Procedia, 96, 628-637 (2018) 